\title{
scripted
}

Volume 16, Issue 1, August 2019

\section{Bringing the EU Competition Rules in the Digital Market - the Commission Decision in the Google Android Case}

\author{
Vasil Stoynov* \\ (ㄷ) (1) $(9)$ \\ (C) 2019 Vasil Stoynov \\ Licensed under a Creative Commons Attribution-NonCommercial- \\ NoDerivatives 4.0 International (CC BY-NC-ND 4.0) license
}

DOI: $10.2966 /$ scrip.160119.49

\begin{abstract}
The majority of reactions to the Commission's decision to impose a fine on Google because of its anticompetitive practices regarding the mobile operating system Android were mainly focused on the record-breaking size of the penalty on the company and the political message that some analysists see in the context of the tense EU - USA economic relations. However, the importance of the proceeding against Google's commercial conduct reaches far beyond. The arguments of the Commission have the potential to show to what degree the settled understanding and practice on the abuse of dominant position can be applied in the digital technology markets. From a broader perspective the approach of the authority could also shape the role of the antitrust policy and rules for the innovation process and can potentially influence the way technology companies do business in Europe. Having something to learn from its experience with other proceedings against USA big tech companies, the EU watchdog has to seize the opportunity to prove that it is fit to provide robust application of antitrust rules in the digital $21^{\text {st }}$ century.
\end{abstract}




\section{Keywords}

Competition, abuse of dominant position, mobile operating systems, internet search, Google, Android, European Commission

* PhD Student, Administrative Law Department, Sofia University "St. Kliment Ohridski", Sofia, Bulgaria, stoynov.vasil@gmail.com 


\section{Introduction}

On the 18th of July 2018, the US technology giant Google received some very disturbing, yet not unexpected news from across the Atlantic Ocean. The European Commission announced its decision to impose on Google a recordbreaking fine of 4.34 billion Euros for its illegal restrictions and anticompetitive practices regarding Android mobile devices.

According to Commissioner Vestager, the main concern in this case is that Google has used Android as a "vehicle to cement the dominance of its search engine" and thus has denied the EU consumers the benefit of effective competition in the market of online internet search services. ${ }^{1}$

More precisely, the competition authority raised three allegations of anticompetitive market behaviour by Google. The first claim is focused on a tying practice whereby the company requires manufacturers of mobile devices to preinstall some of the proprietary products in order to receive a license for other products. The second claim is that Google has granted financial incentives to some of the manufacturers on condition that they exclusively pre-install Google's applications on the devices. Lastly, the company is alleged to be using an "AntiFragmentation Agreement" in order to bar phone makers from selling devices running on modified and alternative Android systems.

This case comment will address each of the arguments outlined in the Statement of Objections and further explained in the press release of the decision. It will start with the question of the relevant market and will further present the precise allegations with a critical analysis of the anticompetitive issues in the light of the existing case law and antitrust practices. Lastly, the article will conclude

1 European Commission, "Press release IP/18/4581" (18 July 2018), available at http://europa.eu/rapid/press-release IP-18-4581 en.htm (accessed 5 September 2018). 
with an assessment of the challenges for the proceeding and the importance of the case.

\section{Relevant market}

The first step in any assessment of anti-competitive behaviour is to properly define the relevant market in order to assess and calculate the market shares of a company and to identify its market power. ${ }^{2}$ The relevant market comprises of all those products and/or services which are regarded as interchangeable or substitutable by the consumer with a view to their characteristics, prices, and intended use. ${ }^{3}$

In the Google Android case the Commission distinguished three markets and it held that the company has more than $90 \%$ market share in each. ${ }^{4}$ The first one is the market for "general internet search services". From the way the market is defined it seems that the Commission considered the internet search on the PC and the internet search on mobile devices (smart phones and tablets) as substitutes. The relevant market is determined in the same way as in the other decision against Google regarding its comparison shopping service. ${ }^{5}$ However, this approach shows inconsistency since in the Google Android case the authority is not concerned with Google's conduct in internet search in general, but only with its business strategy for search and browser apps within Android - the operating system for mobile devices. Furthermore, since the boom in the mobile industry in 2007 the mobile applications have been observed as direct

2 Volkswagen AG v Commission, [2000] ECR II-2707 (ECJ), para. 230.

3 European Commission, "Commission Notice on the definition of the relevant market for the purposes of Community competition law, OJ C 372", (9 December 1997), para. 7.

4 European Commission, "Fact Sheet, MEMO/16/1484" (20 April 2016), available at http://europa.eu/rapid/press-release MEMO-16-1484 en.htm (accessed 5 September 2018).

5 Google search (Shopping) (Case AT.39740) Commission Decision C 4444 [2017] OJ C9/11 paras. 155-190. 
competitors to general search engines and there is a clear trend for consumers switching from traditional browsing to products providing more direct and focused portals of information. ${ }^{6}$ There is empirical economic analysis showing that the process of browsing is different and less costly for PC users in comparison to mobile phone users due to factors such as the relationship between the rank of a post in the search results and a possibility for a click on that post. ${ }^{7}$ Also the supply side of the browsing service on PCs and mobile devices shows differences which were addressed by Google in 2016, when it announced its "Mobile first indexing" - an adaptation of its search index intended to target primarily the mobile version of a site's content. ${ }^{8}$ It follows that both from the supply and demand side perspective the browsing on mobile devices is not substitutable to PC browsing and thus there are two separate markets for internet search services, only one of which should be the relevant market in the case of Google Android - the market for mobile search services.

According to the Commission, the second relevant market comprises of the "licensable smart mobile operating systems". ${ }^{9}$ Two key aspects have to be taken into account in this definition. The first one is the "licensable" characteristic of Android. Although the main feature of the operating system is that it is open source, i.e. everyone can download it for free and modify it, it is still subject to

6 Aaron Edlin and Robert Harris, "The Role of Switching Costs in Antitrust Analysis: A Comparison of Microsoft and Google" (2003) 15(2) Yale Journal of Law and Technology 171-213, p. 207.

7 Anindya Ghose, Avi Goldfarb, and Sang Pil Han, "How Is the Mobile Internet Different? Search Costs and Local Activities" (2012) 24(2) Information Systems Research 1-9, p. 2.

8 Doantam Pham, "Mobile-first Indexing" (Google's Webmaster Central Blog, 04 November 2016), available at https://webmasters.googleblog.com/2016/11/mobile-first-indexing.html (accessed 10 November 2018).

9 European Commission, "Fact Sheet, MEMO/16/1484" (20 April 2016), available at http://europa.eu/rapid/press-release MEMO-16-1484 en.htm (accessed 5 September 2018). 
licensing (without a license fee), mostly under the Apache Software License. ${ }^{10}$ In Google's business model the revenue flows not from the licenses, but from the consumers' use of proprietary applications - such as Gmail, Google Maps, and Google Search. ${ }^{11}$ The second issue is whether this market also includes other operating systems for mobile devices such as iOS (owned by Apple). iOS is different from Android because it is proprietary to the manufacturer of the mobile devices and is used exclusively on those devices. ${ }^{12}$ Therefore iOS as the second most popular operating system in Europe ${ }^{13}$ is not a substitute for Google's product from the demand side perspective. In other words, if the direct customers of Google - the original equipment manufacturers (OEMs) - would like to switch to a new operating system, they will not be able to choose iOS since it is run only on the devices produced by Apple and is not licensed to any other company. There are also further major differences between the economic, intellectual property, and business models of the systems that do not allow for them to be considered as substitutes. ${ }^{14}$ Currently in the same relevant market as Android there are a few licensable open source operating systems as Sailfish, ${ }^{15}$

10 Android Official Website, "Content License" available at https://source.android.com/source/licenses.html (accessed 5 September 2018).

11 Gerard Goggin, "Google Phone Rising: The Android and the Politics of Open Source" (2012) 26(5) Continuum: Journal of Media \& Cultural Studies 741-752, p. 743.

12 Supra n. 4. In the first footnote it is pointed out: "Android is a licensable operating system meaning that third party handset manufacturers can use it for their devices; as opposed to operating systems exclusively used by vertically integrated developers".

13 StatCounter Global Stats, "Mobile Operating Systems Market Share Europe" available at http://gs.statcounter.com/os-market-share/mobile/europe/\#monthly-201709-201809 (accessed 9 December 2018).

14 Scott Cleland, "Google Android has 90\% OS share because Apple iOS isn't a direct competitor" (Precursorblog, 29 May 2015), available at http://precursorblog.com/?q=content/google-android-has-90-os-share-because-apple-iosisn\%E2\%80\%99t-a-direct-competitor (accessed 5 September 2018).

15 Sailfish OS, "Info", available at https://sailfishos.org/info/ (accessed 5 September 2018). 
Ubuntu, ${ }^{16}$ or Tizen. ${ }^{17}$ The conclusion of the authority is that the consumer's choice in purchasing or switching between Android and iOS devices is not sufficient to constrain Google's dominance in the market for licensable mobile operating systems.

The third defined relevant market is the "app stores for the Android mobile operating system". ${ }^{18}$ The Commission considers that specific apps (such as Google Play) which serve as a store for other apps constitute a separate market. Such a conclusion could follow from the fact that Google Play faces direct competition from other products with the same functionality - to allow customers to download Android-compatible mobile applications. ${ }^{19}$ Nevertheless,

the authority should provide convincing data to prove whether those apps are sufficiently different from any other apps and therefore not substitutable for the users and the device manufacturers. As explained below, this particular market is needed for the assessment of the anticompetitive tying.

In conclusion, even if the definitions of the relevant markets raise some concerns, the dominance of Google is most likely not going to be disproved as the estimations of the market shares by the Commission are well supported by statistical data. ${ }^{20}$

16 Ubuntu, "Mission", available at http://www.ubuntu.com/about/about-ubuntu/ourphilosophy (accessed 5 September 2018).

17 Tizen, "About", available at https://www.tizen.org/about (accessed 9 December 2018).

18 European Commission, "Fact Sheet, MEMO/16/1484" (20 April 2016), available at http://europa.eu/rapid/press-release MEMO-16-1484 en.htm (accessed 5 September 2018).

19 Examples of app stores which are direct competitors to Google Play are: Amazon AppStore, GetJar, Mobogenie, SlideME, F-Droid, Aptoide, Uptodown, APKUpdater.

20 Matt Rosoff, "Here's How Dominant Google Is In Europe" (Business Insider, 29 November 2014), available at http://www.businessinsider.com/heres-how-dominant-google-is-ineurope-2014-11?IR=T (accessed 5 September 2018). 


\section{Allegations by the Commission}

\subsection{Anticompetitive tying}

The Commission claims that Google is concluding contracts with mobile phone manufacturers whereby the licensing of the app store Google Play is made conditional upon the pre-installation and setting as default of two other applications - Google Search and the mobile browser Chrome. In the antitrust context, this strategy is described as "contractual tying", which refers to situations where customers that purchase one product (the tying product) are required also to purchase another product from the dominant undertaking (the tied product)..$^{21}$ In the present case the tying product is the application Play Store which is essentially important for the users as a gateway to a vast number of other applications. ${ }^{22}$ Google's app store is not open source like the Android operating system, meaning that the manufacturers have to obtain the license for the application. Google is allegedly using the essentiality of the Play Store to force the OEMs to also install as default two other Google products that have or might have substitutes by competitors - Google Search and Chrome.

The strategy is not hard to follow - the company is absolutely dominant in the market of traditional internet search on computers and receives most of its revenue from advertising. However, the rapidly developing market of mobile devices offers other possibilities for browsing and because the internet is

21 Communication from the Commission 2009/C 45/02 of 24 February 2009 providing guidance on the Commission's enforcement priorities in applying Article 82 of the EC Treaty to abusive exclusionary conduct by dominant undertakings [2009] OJ 2009/C 45/02, para. 48.

22 According to the Statistics Portal "Statista", as cited in the website "Business of Apps", Play Store reached 3 million apps in June 2017, available at http://www.businessofapps.com/data/app-statistics/\#2 (accessed 9 December 2018). 
"Google's piggy bank", ${ }^{23}$ the firm is aiming to extend its dominance also to the mobile internet through the tying and bundling practices and then again monetise its ubiquity through the advertising business model.

The European Commission already has a significant experience with a tying and bundling case against another US technological giant - Microsoft, which was fined with 497 million Euros for refusal of supply and for anticompetitive tying. ${ }^{24}$ In the judgement confirming the Commission decision the Court found that the company is tying Windows Media Player (the tied product) to the Windows client PC operating system (the tying product). ${ }^{25}$ In the Android case the tied products are the applications Google Search and Google Chrome and the tying product is the application Play Store. From the outset it seems that Google is now charged with analogous offence and the outcome of the assessment of its conduct would most likely depend on the references to the Microsoft judgement and their interpretation. ${ }^{26}$

The Court in its decision outlined four conditions that have to be met in order for an abusive tying to be established. ${ }^{27}$ Firstly, the tying and tied products must be two separate products. Secondly, the concerned undertaking must be dominant in the market for the tying product. Thirdly, the undertaking must not give customers the choice to obtain the tying product separately, and lastly, the practice must have a foreclosure effect.

23 Matt Asay, "Google's master plan for Android: More Internet users paying \$6.30 a pop" (TechRepublic, 8 January 2014), available at http://www.techrepublic.com/article/googlesmaster-plan-for-android/ (accessed 5 September 2018).

24 Microsoft (Case COMP/C-3/37.792) Commission Decision C(2005)4420 [2008] OJ C 138/10, para. 1078.

25 Microsoft $v$ Commission, [2007] ECR II-3601 (ECJ).

26 Jennifer Rankin, "EU accuses Google of using Android to skew market against rivals" (The Guardian, 20 April 2016), available at https:/www.theguardian.com/technology/2016/apr/20/eu-commission-google-androidskew-market-competition-antitrust-vestager (accessed 5 September 2018).

27 Supra n. 24, para. 842. 
In the situation with Google the first essential point would be whether Play Store and the other two applications - Google Search and Google Chrome belong to two different markets. If this condition is not met, i.e. if there is no independent demand for the tied product, there cannot be a case of abusive tying. ${ }^{28}$ The differentiation between the products must be observed from the customer demand perspective, ${ }^{29}$ which means that the two products would be distinct if, in the absence of tying or bundling, a substantial number of customers would purchase the tying product without also buying the tied product from the same supplier. ${ }^{30}$ In other words, it is essential to establish whether the OEMs (which are the direct customers of Google) would be interested to install only Play Store on their devices, without also installing Google Search or Chrome, if Google was not tying these products together. Additionally, the technological features of the products must also be taken into account. ${ }^{31}$

In its defence, according to the press release on the decision, ${ }^{32}$ Google has raised the argument that the tying practice was necessary in order for the company to monetise its investments in Android. Such a plea falls directly under the explicit prohibition of art. 102 (d) of the Treaty on the Functioning of the EU (hereinafter 'TFEU') and the Court of Justice of the EU would under no circumstances justify a foreclosing anticompetitive abuse on the grounds that the undertaking seeks to gain more profits. What actually might be a successful position for the company is that all three products belong to a single market of applications compatible with the Android system (along with other proprietary apps such as Google Maps, Google Drive etc.) and are therefore offered as a

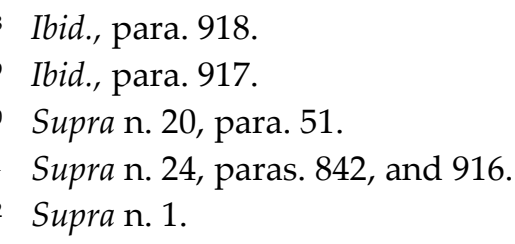


package. However, from the consumer's demand perspective Play Store has a significantly different functionality than Google Search or Chrome and therefore Google would have to convincingly prove that the two products are likely to be substitutable. Another argument for Google could be that there is a natural link between the products - a condition, which discards the illegal nature of the tying according to the wording art. 102 (d) TFEU. However, the Court interpreted this exception very narrowly in the Microsoft case, therefore Google will probably not succeed with such a plea. ${ }^{33}$ It follows that unless Google shows some convincing evidence that the applications belong to one single market, the first condition for abusive tying would be met.

The second condition, according to the preliminary analysis of the Commission, also seems to be fulfilled since Google possesses a market share of over $90 \%$ in the market of app stores.

The third condition relates to the possibility for the consumers to obtain the tying product from a different source. According to the facts Google creates contractual barriers for the OEMs to pre-install other browsing and internet search apps, but does not prevent the download and use of competing apps by consumers. Therefore the real question is whether Google creates anticompetitive foreclose of the effective competition on the market by disincentivising consumers to use competing apps even if they are of a better quality than Google's own products. ${ }^{34}$ In its press-release the Commission quotes an example from 2016 where users of Android devices made more than $95 \%$ of all search queries via the Google Search app whereas the users of Windows Mobile devices made less than $25 \%$ of the queries via Google's app. ${ }^{35}$ This

33 Supra n. 24, paras. 941-942.

$34 \quad$ Ibid., para. 974.

35 Supran. 1. 
example suggest that users would rather use the pre-installed search app instead of downloading and using another app. However, more empirical data is needed for the Commission to prove that users search extensively with Google not because Google Search and Chrome are better products, but because they have them as default.

The fourth condition requires from the competition authority to prove that actual anticompetitive effect takes place on the market in the form of foreclosure. In Microsoft's case the Commission did not accept the conduct of the company as a classical tying and therefore unlike in other cases it sought to demonstrate that the pre-instalment of Windows Media Player had the inevitable and effective consequence of altering the balance of competition in favour of the undertaking and to the detriment of the other operators. ${ }^{36}$ In order to do so, the authority introduced a three-step analysis. The Court did not follow the "rule of reason" approach to the foreclosure effect ${ }^{37}$ and found that the threat to the structure of the competition was sufficient to fulfil the fourth element of the anticompetitive tying. ${ }^{38}$ Therefore the Commission in Google's case might find it easier to prove the last condition only by showing how the company's conduct is changing the competitive structure in the mobile search market.

It follows from the above that although Google is tying its internet search applications to a store application and not to the Android system itself, the level of ubiquity of Play Store is significantly enough to put other competitors at a disadvantage in distributing their internet search products. However, Google

36 See Hilti AG v Commission (1994) ECR I-667 (ECJ) and Tetra Pak International SA v Commission (1996) ECR I-5951 (ECJ).

37 Christian Ahlborn and David Evans, "The Microsoft Judgement and its Implications for Competition Policy Towards Dominant Firms in Europe" (2009) 75(3) Antitrust Law Journal, p. 14.

38 Supra n. 24, para. 1058. 
Search and Chrome are also ubiquitous, as services in the traditional PC internet search, therefore the anticompetitive effect is more likely to consist not in boosting the popularity of the tied product, but in the increased barriers to entry of new products that might be better than Google Search and Chrome. Indirectly, this conduct also deters innovation in new internet search technologies. The consumers' choice is also affected because they do not have incentive to switch to another browsing product although they have an opportunity to do so. ${ }^{39}$

In conclusion, the first allegation against Google would be decided in the light of the Court's findings in the Microsoft case. It seems that the Commission would be able to prove the four conditions for anticompetitive tying in the commercial conduct of Google which is very similar to the one of Microsoft.

\subsection{Exclusivity}

The second allegation of the Commission is that Google is offering manufacturers and mobile network operators financial incentives on the condition that they preinstall Google Search on their devices. In other words, Google is buying the exclusivity of its search engine for mobile devices. Furthermore, the Commission asserts that it has evidence showing that some of the manufacturers indeed were affected by this practice and did not pre-install competing search services.

From the way the authority formulated its concerns it is not really clear what exactly the type of the alleged infringement is. More precisely, it is not certain under what conditions did Google offer financial incentives, i.e. were they implemented in the licensing agreements for Android, were they based on discounts or rebates from the licenses of the proprietary applications or offered as shares from the advertising revenue etc. Those details might have an impact

$39 \quad$ Ibid., para 971. 
on the way the Commission approaches the case since the Guidance paper ${ }^{40}$ and the Court ${ }^{41}$ draw a line between the exclusive purchasing contracts and the discount or rebate schemes.

However, even without having additional information on the facts, it is worth noticing that in the case law, there is a tendency of a more effect-based approach in the assessment of cases on exclusivity under Article 102 TFEU. ${ }^{42}$ It follows that the Commission would have to prove that the competitors were foreclosed from the market or customers are disadvantaged due to the exclusive pre-instalment of Google Search. At the same time Google would have the opportunity to show efficiencies arising from its conduct in the form of cost or other advantages which are passed on to consumers. ${ }^{43}$

\subsection{Anti-fragmentation}

The last concern of the Commission is related to a commercial practice of Google called "Anti-Fragmentation Agreement" under which the OEMs are obliged to sell devices running only on the Android system that is developed by Google itself. As explained above, the main feature of the system is that anyone can download it and receive a license for free, modify it, and build a phone. ${ }^{44}$ The modifications that can be made in the system are called "forks" and manufacturers are entitled to use them on their own devices (for example, forks are used by Amazon on its Fire tablets or by the manufacturers in China, where

40 Supra n. 20, para. 32.

41 Compare Hoffman-La Roche v Commission, (1979) ECR 461(ECJ) and Manufacture Française des Pneumatiques Michelin v Commission, (2003) ECR II-407 (ECJ).

42 Alison Jones and Brenda Sufrin, EU Competition Law: Text, Cases, and Materials (Oxford: OUP, 2014), p. 452.

43 Supra n. 20, para. 48.

44 Kent Walker, "Android's Model of Open Innovation" (Google Europe Blog, 20 April 2016), available at http://googlepolicyeurope.blogspot.de/2016/04/androids-model-of-openinnovation.html (accessed 5 September 2018). 
Google's services are blocked). However, according to the allegations, Google is leveraging its proprietary apps and most importantly Google Play in order to incentivise the OEMs to install only the company's version of the Android system.

The conduct of the company can again be characterised by tying but, unlike in the Microsoft case, here the tying product is the application (Play Store) and the tied product is the operating system (Google's Android version). However, the big difference between the cases lies in the open source character of Android. In the context of the antitrust rules the possibility for any manufacturer to create its own independent version of the operating systems neutralises any real dominance of Google and diminishes the risk of anticompetitive abuse. ${ }^{45}$ Google is proudly highlighting this feature of Android and claims that the system is "spurring this competition and choice, lowering prices and increasing choice for everyone". ${ }^{46}$

The issue with the open source trait deserves a closer examination. Without going into very technical details, it is enough to point out that Android consists of a kernel (based on the PC operating system Linux), libraries, a Java platform, and applications. Some parts of the Linux that is included in Android are not free, as well as some of the libraries and many of the applications. This makes the source code of the Android version, which is licensed as free software,

45 Carl Mair, "Paranoid Android? EU Commission vs. Google's mobile Android OS" (Leiden Law Blog, 21 April 2016), available at http://leidenlawblog.nl/articles/paranoid-android-eucommission-vs.-googles-mobile-android-os (accessed 5 September 2018).

46 Hiroshi Lockheimer, "Android has helped create more choice and innovation on mobile than ever before" (Google Europe Blog, 15 April 2015), available at http://googlepolicyeurope.blogspot.de/2015/04/android-has-helped-create-more-choice.html (accessed 5 September 2018). 
not sufficient to run a functional device. ${ }^{47}$ Another aspect is that even if we assume that Android is a really open source product, this does not exclude the possibility for Google to discard Android's open source nature through de facto limitations, as the Commission claims. The result from the combination between the open source nature of the system and the alleged anticompetitive commercial strategy of marketing resembles a guided democracy. ${ }^{48}$

The Commission claims that it has evidence that the company's conduct prevents manufacturers from selling devices based on a competing Android fork. If there is such evidence that would make the bundling of Google's Android with Play Store a clear-cut anticompetitive conduct. Google's position is that unlike Microsoft it does not prevent competitors from developing apps for Android and that other companies successfully run devices on different Android systems. ${ }^{49}$ Such an argument is not convincing because the emphasis that the Court put on the Microsoft judgement was not on the detrimental effect of specific undertakings, but on the market structure..$^{50}$ Therefore, if an anticompetitive foreclosure of competitors that develop Android forks is established by the Commission, the critical point in the proceedings would be shifted from the question whether there is antitrust violation to the question of whether it is justified.

Here the main argument of the company is based on the efficiency and the sound functioning of the Android "ecosystem". ${ }^{51}$ According to Hiroshi Lockheimer, the Senior Vice President for Android, Chrome and Chromecast, the

\footnotetext{
47 Richard Stallman, "Is Android really free software?" (The Guardian, 19 September 2011), available at https://www.theguardian.com/technology/2011/sep/19/android-free-softwarestallman (accessed 5 September 2018).

48 Supra n. 10, p. 749.

49 Supra n. 45.

50 Supra n. 41, p. 505.

51 Supra n. 43.
} 
anti-fragmentation agreements ensure that apps work across all sorts of different Android devices. ${ }^{52}$ In essence, the company claims that by inducing OEMs to install Google's version of Android it provides a guarantee to the users for reliable and smooth operation of the applications. This matter is of a very technical character and needs to be addressed by experts, but it is not hard to accept that if each manufacturer uses a different "fork" this might lead to higher costs for ensuring the compatibility by the developers, as well as to some discrepancies in the functionality of the systems. Google's position would have to be supported by a very solid proof as the standards of the Court of Justice for the justification of a tying practice on reasons of "technical efficiency" are very high. In the Microsoft case the attempt of the company to prove that disintegration of Windows Media Player from the Windows operating system would create a series of problems to the detriment of consumers, software developers, and internet site creators was firmly rejected. ${ }^{53}$ The Court did not accept the arguments for the integration of the two products as long as it is technically feasible for them to be marketed separately, which is also the case with Google - the company does not claim that Play Store can work properly only under Google's own Android version, but rather points at the risk of mobile devices running different Android forks in parallel.

However, even if those anti-fragmentation agreements are justified by technical reasons for maintaining interoperability and cohesion of the system, Google's justification for its business model with technical arguments remains unconvincing. As the Commission rightly points out, this is not the only way to incentivise manufacturers to use a specific version of the operating system since that could be achieved inter alia through compliance procedures or conformity

Supra n. 45.

53 Supra n. 24, paras. 1144-1167. 
agreements. The effect of the practice is in any case limiting the OEMs in their independent decision as per which particular system to use and this anticompetitive effect requires a really sound and thorough justification from Google, otherwise it would fall under the prohibition of Article 102 TFEU.

\section{Conclusion}

The assessment of the Google Android case must have as a starting point the clear message that the dominance of the company is not by itself a threat and that the products that it offers benefit a vast number of consumers and undertakings in Europe. The EU competition policy, however, requires a specific responsibility from the dominant undertakings ${ }^{54}$ and therefore the concerns that Google is "stifling competition and restricting innovation in the wider mobile space" 55 must be carefully addressed. The thorough scrutiny from the Commission should not fall under the accusations of "abusing U.S. companies" 56 because it is fully justified given the impact of the major internet platforms to the consumers in Europe.

The EU antitrust watchdog, nevertheless, has a few lessons to learn from the past. The period from the launch of the investigation against Microsoft to the judgement of the General Court took 12 years, and the remedies imposed on the company had no noticeable effect on the marketplace. ${ }^{57}$ Such a result in the

54 France Télécom v Commission, [2009] ECR I-2369 (ECJ), para. 105.

55 European Commission, "Statement 16/1506" (20 April 2016), available at http://europa.eu/rapid/press-release STATEMENT-16-1506 en.htm (accessed 5 September 2018).

56 Senate Finance Committee Chairman Orrin Hatch, cited in Nicholas Hirst, Nancy Scola, and Tony Romm, "Europe's Android case sharpens divide with US" (Politico, 20 April 2016), available at http://www.politico.eu/article/europes-android-case-sharpens-divide-with-us/ (accessed 05 September 2018).

57 Nicholas Economides and Ioannis Lianos, "A Critical Appraisal of Remedies in the E.U. Microsoft Cases" (2010) Columbia Business Law Review 346-400, p. 385. 
Google Android case is not desirable, therefore the Commission should prioritise the swift conclusion of the proceeding. In the meantime, many features of the digital market can change. Google's dominance might very likely be diminished in the event of a new breakthrough in technology - such as virtual reality, wearable gadgets, chatbots, or even artificial intelligence. ${ }^{58}$ If, however, the relevance of the case against the company does not dwindle, the remedies that are expected could be practically enforced without delay since Google would have to change its commercial conduct, not the technology itself. That would be the desired outcome of the case for the Commission - eliminating the foreclosure imposed by the biggest market player and thus ensuring competition on the merits in the area of search engine services, in particular on mobile devices. It might be hard at the moment to image how an actual competitor of Google will emerge after the foreclosure is diminished, but the Commission is showing consistency in focusing not on the specific undertakings, but on the market itself and on the efforts to keep the competition in the digital world as effective as possible, trusting in the powers of technological drive and innovation. ${ }^{59}$

From a broader perspective, the Google Android case can be observed as a test for the Commission to carry out the EU competition policy in the world of the digital technologies and to prove the relevance of the antitrust rules in the digital market. It is true that internet has changed the lives of everyone in Europe. However, the new technologies have not altered the way the market economy is functioning. Although the digital platforms differ from traditional economic

58 Nickolas Hirst, “Google's winning card against Europe: time” (Politico, 25 April 2016), available at http://www.politico.eu/article/why-the-ec-may-ultimately-lose-the-android-case/ (accessed 5 September 2018).

59 For instance, in Microsoft/Skype (Case COMP/M.6281) Commission Decision [2011] C268/09 the Commission allowed the merger of Microsoft and Skype despite the market share of $90 \%$ as long as the market for communication services has very low entry barriers for competitors. 
models, the EU internal market remains rooted in the cornerstone ideas of fair competition on the merits and consumer choice. There is no reason for the antitrust rules not to apply in the market of digital technologies. However, the enforcement of these rules must take specific account of the fundamental features of the market such as the possibility for competitors to enter, the incentives for technological progress, and the preservation wide range of digital services. ${ }^{60}$

In conclusion, the case against Google's Android would be a significant step for the antitrust policy if the Commission not only looks at past experience, but also implements the trends that would define the information technology and the digital economy in the next decades. The authority must adopt a more "technological" and "behavioural" approach, ${ }^{61}$ taking into account the dynamic development in the digital markets and the way the new economic models interact with consumers. The arguments of the Commission presented so far are convincing, but the decision would be upheld by the Court if the authority shows not only robust arguments and evidence, but also genuine understanding of the specifics of the digital economy and willingness to strike a balance between fostering the innovation and protecting the competition.

60 Herbert Hovencamp, "Antitrust and Information Technologies" (2015) 68 Florida Law Review 419-465, p. 464.

61 Gintare Surblytè, "Competition Law at the Crossroads in the Digital Economy: Is it All About Google?" (2015) 9(5) EuCML 170-178, p. 178. 